\title{
Isolation of viral hemorrhagic septicemia virus from Greenland halibut Reinhardtius hippoglossoides caught at the Flemish Cap
}

\author{
C. P. Dopazo ${ }^{1, *}$, I. Bandín ${ }^{1}$, C. López-Vazquez ${ }^{1}$, J. Lamas ${ }^{2}$, M. Noya ${ }^{2}$, J. L. Barja ${ }^{1}$ \\ ${ }^{1}$ Departamento de Microbioloxía e Parasitoloxía, and ${ }^{2}$ Departamento de Bioloxía Celular, Instituto de Acuicultura/Facultade \\ de Bioloxía, Universidade de Santiago de Compostela, 15782, Spain
}

\begin{abstract}
Viral hemorrhagic septicemia virus (VHSV) was isolated from apparently healthy Greenland halibut Reinhardtius hippoglossoides caught in the Flemish Cap, a deep fishing ground in the North Atlantic Ocean in international waters near Newfoundland. The identity of the virus was confirmed by electron microscopy, immunodot, seroneutralization and reverse transcriptasepolymerase chain reaction. In the serology assays, all isolates reacted in the immunodot assay with a polyclonal antiserum against the European VHSV Type Strain F1, and were neutralized by the same antiserum, although most of the strains showed low or moderate neutralization titers. None of the isolates were detected by immunofluorescence using a specific monoclonal antibody against a nucleocapsid-related protein of VHSV F1. This is the first report of VHSV isolated from wild Greenland halibut, which represents a new host species for the virus, and it is also the first evidence of VHSV in a location close to the Atlantic coast of North America. This isolation indicates that VHSV is more widely distributed than has been thought, and appears to support a marine origin of this virus.
\end{abstract}

KEY WORDS: Viral hemorrhagic septicemia virus $\cdot$ VHSV $\cdot$ Greenland halibut · Wild fish Resale or republication not permitted without written consent of the publisher

\section{INTRODUCTION}

Viral hemorrhagic septicemia virus (VHSV), a rhabdovirus belonging to the genus Novirhabdovirus, is an economically important fish pathogen causing high mortalities among farmed rainbow trout Oncorhynchus mykiss throughout Europe. In addition, it has been isolated in different areas of European waters from other fish species such as farmed turbot Scophthalmus maximus (Schlotfeldt et al. 1991, Ross et al. 1994), as well as wild Atlantic cod Gadus morhua (Jensen et al. 1979, Jorgensen \& Olesen 1987, Smail 1995, 2000, Munro 1996, Mortensen 1999, King et al. 2001), the haddock Melanogrammus aeglefinus (Munro 1996, Smail 2000), the Atlantic herring Clupea harengus (Dixon et al. 1997, Mortensen 1999, King et al. 2001), and other marine fish species (Mortensen 1999, King et al. 2001). On the Pacific coast of North

*E-mail: mpdopazo@usc.es
America, isolations have been reported for a number of fish species including chinook Oncorhynchus tshawytscha and coho O. kisutch salmon (Brunson et al. 1989, Hopper 1989, Eaton et al. 1991), the Pacific cod G. macrocephalus (Meyers et al. 1992), the Pacific herring C. harengus pallasi (Meyers et al. 1994, Traxler \& Kieser 1994, Kent et al. 1997, Marty et al. 1998, Hershberger et al. 1999), the Pacific hake Merluccius productus and the walleye pollack Theregra chalcogramma (Meyers et al. 1999), the shiner perch Cymatogaster aggregata (Kent et al. 1997), and more recently, from the smelt Thaleichthys pacificus (Kaufman \& Holt 2001), the Pacific sardine Clupea sp., and the mackerel Scomber sp. (Cox \& Hedrick 2001).

The increasing number of isolations from marine fishes, together with the established susceptibility of numerous marine and freshwater species to the virus (Meier et al. 1994), has led to a re-consideration of the epidemiology of this virus. In this sense, it has been suggested that the VHSV has been enzootic in the Pacific Ocean and European waters for quite a long 
time (Stone et al. 1997), and that in mainland Europe it may have originated from a marine source (Batts et al. 1993, Meyers \& Winton 1995, Dixon et al. 1997, Stone et al. 1997, Dixon 1999).

In the present paper we report the first isolations of VHSV from Greenland halibut Reinhardtius hippoglossoides caught during a research campaign ('Flemish Cap'94') to evaluate fish stocks in a Newfoundland fishery in the North Atlantic Ocean, and discuss the possible origin of this virus.

\section{MATERIALS AND METHODS}

Cell lines. Monolayers of chinook salmon embryo (CHSE-214), epithelioma papillosum cyprini (EPC) and rainbow trout gonad (RTG-2) cells were used for the primary detection of the virus. Other fish cell lines used to test the host range of the virus were brown bullhead (BB) and TV-1 (from turbot fin). All cell lines were grown in Eagle's minimum essential medium (EMEM, Gibco) supplemented with $10 \%$ foetal calf serum (FCS, Gibco), 100 I.U. $\mathrm{ml}^{-1}$ penicillin and $100 \mu \mathrm{g}$ $\mathrm{ml}^{-1}$ streptomycin. The CHSE-214 cells were grown at $15^{\circ} \mathrm{C}$, RTG-2 and TV-1 at $20^{\circ} \mathrm{C}$ and $\mathrm{EPC}$ and $\mathrm{BB}$ at $25^{\circ} \mathrm{C}$. Confluent monolayers of all cell lines were maintained at $15^{\circ} \mathrm{C}$, and the medium substituted by EMEM with 0 or $2 \%$ FCS.

Virus isolation. Various species of fishes were caught in a research campaign ('Flemish Cap'94') during July 1994, led by the Instituto de Investigacións Mariñas (Vigo, Spain) as a part of an EU project to evaluate fish stocks in that fishery. Flemish Cap is a
Newfoundland fishing ground located in international waters in the North Atlantic Ocean (Fig. 1A) where fishes are captured under NAFO (North Atlantic Fisheries Organization) surveillance.

A total of 80 asymptomatic fishes (38 Atlantic cod, 30 Greenland halibut, 7 witch flounder Glyptocephalus cynoglossus and 5 American plaice Hippoglossoides platessoides limandoides) were collected along different trawling transects (Fig. 1B) at depths between 200 and $500 \mathrm{~m}$. The fishes were aseptically dissected, and spleen and kidney were immediately frozen at $-20^{\circ} \mathrm{C}$ for further examination in our laboratory in Santiago de Compostela.

Tissues from each individual fish were mixed (1:5) with Earle's buffer (Gibco), supplemented with antibiotics (1000 I.U. ml ${ }^{-1}$ penicillin, $1000 \mu \mathrm{g} \mathrm{ml}^{-1}$ streptomycin, $500 \mu \mathrm{g} \mathrm{ml}^{-1}$ gentamycin and $10 \mu \mathrm{g} \mathrm{ml}^{-1}$ amphotericine B) and homogenized. After centrifugation of the homogenates at $2000 \times g$ for $15 \mathrm{~min}$, the supernatants were transferred to new tubes, incubated for $4 \mathrm{~h}$ at $15^{\circ} \mathrm{C}$, and inoculated (diluted up to $1 / 10$ and 1/100) in triplicate onto confluent monolayers of CHSE-214, RTG-2 and EPC cells, in 24-well plates. The cultures were incubated at $15^{\circ} \mathrm{C}$ and examined daily to detect development of a cytopathic effect (CPE). After $15 \mathrm{~d}$, positive and negative samples (cultures showing $\mathrm{CPE}$ or no-CPE, respectively) were subjected to a second or blind passage (respectively) by inoculating $0.1 \mathrm{ml}$ of the scraped cell suspension onto new cultures. Both second and blind passages were terminated after $21 \mathrm{~d}$ of incubation. Non-infected cells were used as controls. Crude virus, i.e. cell suspensions from positive samples, was maintained at $-70^{\circ} \mathrm{C}$ until use.

A

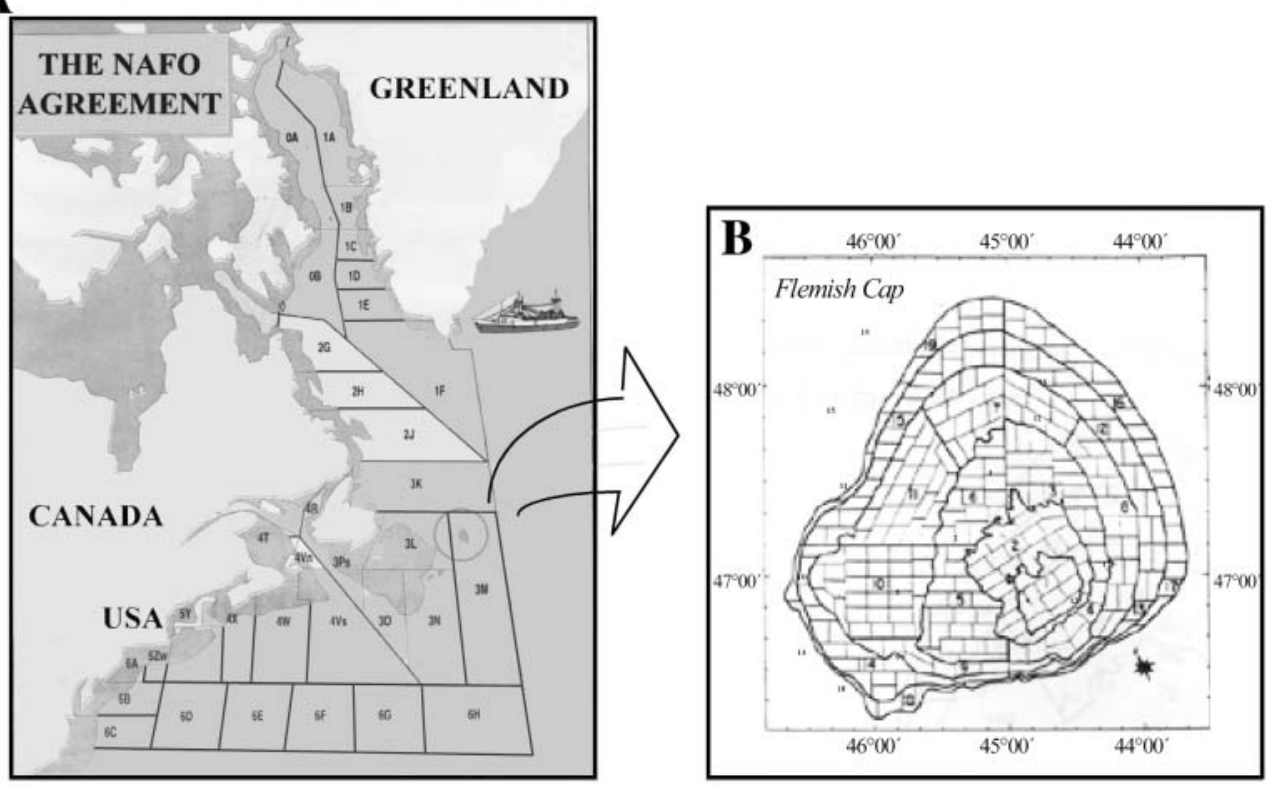

Fig. 1. Locations of (A) Flemish Cap fishing ground, and (B) trawling transects. NAFO: North Atlantic Fisheries Organization 
Physicochemical characterization. The sensitivity of viral isolates to chloroform was examined according to a modification of the method of Jørgensen (1972). Turbot aquareovirus (TRV) and infectious hematopoietic necrosis virus (IHNV) were used as controls for nonenveloped and enveloped viruses, respectively.

Viral titrations were determined by the tissueculture infectious dose (TCID ${ }_{50}$ ) method, and calculated according to Reed \& Müench (1938), using EPC cells for the halibut isolates and CHSE-214 for IHNV and TRV. Losses of infectivity greater than 1 log were considered evidence of susceptibility to the treatment and consequently of presence of an enveloped virus (Hamparian et al 1963, Meyers 1979).

Electron microscopy. Viral isolates were inoculated at a multiplicity of infection (MOI) of 0.01 to 0.1 in $75 \mathrm{~cm}^{2}$ flasks containing monolayers of EPC cells and incubated at $15^{\circ} \mathrm{C}$. When the CPE became extensive, cells were scraped from the surface of the flasks into the medium, and the suspension was centrifuged for $20 \mathrm{~min}$ at $3000 \times g$ to pellet cell debris. The supernatant was transferred to a new tube and $25 \%$ glutaraldehyde was added to a final concentration of $0.05 \%$. This suspension was centrifuged on a cushion of $30 \%$ sucrose at $21000 \mathrm{rpm}(85000 \times g)(\mathrm{SW} 28.1$ rotor, Beckman) for $1 \mathrm{~h}$ at $4^{\circ} \mathrm{C}$, and the resultant pellet was resuspended in $30 \mu \mathrm{l}$ of TN buffer (Tris $10 \mathrm{mM}, \mathrm{pH} 7.6 ; 150 \mathrm{mM} \mathrm{NaCl}$ ). One drop was placed on a formvar-coated grid and allowed to stand for $10 \mathrm{~min}$. The grids were dried, negatively stained with $1.5 \%$ phosphotungstic acid (pH 6.7), and examined with a Philips CM12 transmission electron microscope.

Cell line susceptibility. For this assay, 24-well plates with confluent monolayers of EPC, CHSE-214, RTG-2, TV-1 and BB cell lines were employed. The medium from each well was removed, and $0.1 \mathrm{ml}$ of virus was inoculated to a MOI between 0.01 and 0.1. After an adsorption period of $1 \mathrm{~h}$, the remaining inoculum was removed and fresh EMEM added. The infected cell cultures were incubated at 10 and $15^{\circ} \mathrm{C}$, and observed daily for evidence of a CPE for a maximum of $21 \mathrm{~d}$. Both time to appearance of a CPE and time to total destruction of the monolayer were used to compare the susceptibilities of the different cell lines to the virus. In addition, viral titers of cultures showing CPE were determined in EPC cells, as described above.

Neutralization test. For identification of the viral isolates, a series of direct neutralization tests was performed. For this purpose, crude virus (approximate titer: $10^{4} \mathrm{TCID}_{50} / 0.1 \mathrm{ml}$ ) was mixed with an equal volume of a 1/100 dilution of the antiserum against VHSV F1 European reference strain (kindly provided by Dr. N. J. Olesen, EU Reference Laboratory for Fish Disease, Aarhus, Denmark). After $1 \mathrm{~h}$ incubation at room temperature, the mixture was inoculated into 4 wells
(100 $\mu \mathrm{l}$ per well) of a 48-well plate with confluent monolayers of EPC cells. The inoculated monolayer was incubated for $1 \mathrm{wk}$ at $15^{\circ} \mathrm{C}$ and visualized daily for development of CPE. IHNV and infectious pancreatic necrosis virus (IPNV) were used as controls. In another set of experiments, an antiserum against IHNV-1 (provided by Dr. de Kinkelin, Institut National de la Recherche Agronomique, Cédex, France) was used.

In a second series of neutralization tests, the 'constant virus-varying antiserum' (CV-VA) method was performed, basically as described by Okamoto et al. (1983). For this purpose the viruses were diluted in EMEM without FCS to obtain a suspension containing approximately $10^{3} \mathrm{TCID}_{50} \mathrm{ml}^{-1}$ (initial viral titers ranging from $10^{7.25}$ to $10^{8.75} \mathrm{TCID}_{50} \mathrm{ml}^{-1}$ ), and the antiserum was diluted from 1/10 to 1/5000 in EMEM. The neutralization antibody titers were calculated according to the Reed \& Müench (1938) method and expressed as the reciprocal of the highest dilution of the antiserum protecting $50 \%$ of the inoculated wells. IHNV and IPNV were used as controls.

Immunodot assay. The immunodot assay was performed as previously described (Dopazo et al. 1992) using nitrocellulose membranes (HA, $0.45 \mu \mathrm{m}$, Millipore) loaded with $10 \mu \mathrm{l}$ of each sample of crude virus (approximate titer $=10^{7} \mathrm{TCID}_{50} \mathrm{ml}^{-1}$ ). IHNV and EMEM with FCS were used as negative controls, and VHSV F1 as a positive control. A dilution of 1:750 of rabbit antiserum against the F1 strain of VHSV was utilized as specific antiserum. Appearance of a blue color indicated a positive reaction.

Indirect fluorescent antibody technique (IFAT). For this assay, samples were inoculated onto monolayers of EPC grown in 24-well plates. When a CPE was clearly visible, the infected cultures were fixed with acetone and the IFAT technique performed as described by Lorenzen et al. (1988). Briefly, the monoclonal antibody (MAb) IP5 B11 (kindly provided by Dr. Olesen) against the nucleocapside of the F1 strain was diluted 1:10 in phosphate-buffered saline and applied as first antibody on the monolayer. After $1 \mathrm{~h}$ incubation at room temperature, fluorescein isothiocyanate-labeled goat anti-mouse immunoglobulin (diluted 1:20) was added as the second antibody, and incubated for $1 \mathrm{~h}$ at room temperature. The monolayer was washed and examined under an epifluorescence microscope. VHSV F1, and IHNV and IPNV, were used as positive and negative controls, respectively.

In addition, the IFAT kit Bio-Fluo VHS (Bio-X, Belgium) for diagnosis of VHSV was employed as indicated by the manufacturer.

RT-PCR assay. Each viral isolate was inoculated at a MOI between 0.01 and 0.1 in $25 \mathrm{~cm}^{2}$ flasks containing confluent monolayers of EPC cells and, when evidence of CPE was first observed, total RNA was 
extracted using Trizol $^{\circledR}$ LS reagent (BRL), as described by the manufacturer. Primers utilized in this assay (VHSV-cm1a: 5'-CGT GCC GTC GAA GAA GAG ATA-3'; VHSV-cm1b: 5'ACT GAT AGC GGG AGA TGG ATG-3') were designed using the software DNASTAR (Lasergene Biocomputing) on the basis of the published sequences of the F1 strain of VHSV. Primers were developed to amplify a 432 bp sequence, partially corresponding to the initial sequences of the glycoprotein (G) coding region. In parallel, RT-PCR assays were also applied employing a primer set (IHNV-cm4) corresponding to internal sequences of the $\mathrm{N}$ gene of infectious hematopoietic necrosis virus (IHNV) (IHNV-cm4a.: 5'-AGA TCG GGG CGG TGC TTA GA-3'; IHNV-cm4b: 5'-CCA TCG CCA TCG TAC TTG AGG ACA-3'), and amplifying a fragment of around $504 \mathrm{bp}$.

The RT-PCR assay was performed using the Access RT-PCR System (Promega). Each reaction tube, containing viral RNA (100 to $200 \mathrm{ng}$ ) and both primers $\left(1 \mu \mathrm{M}\right.$ each), was heated at $95^{\circ} \mathrm{C}$ for $5 \mathrm{~min}$ and then incubated at $45^{\circ} \mathrm{C}$ for $5 \mathrm{~min}$. A mixture of reagents provided by the manufacturer, including dNTP $(1 \mathrm{mM}), \mathrm{MgSO}_{4}(1 \mathrm{mM})$, the reverse transcriptase AMV $(5 \mathrm{U})$ and the Tfl-DNA polymerase $(5 \mathrm{U})$ was added to the tubes, and the reaction mixture subjected to 35 cycles of incubation (denaturation for $30 \mathrm{~s}$ at $94^{\circ} \mathrm{C}$, annealing for $30 \mathrm{~s}$ at $60^{\circ} \mathrm{C}$, and polymerization at $68^{\circ} \mathrm{C}$ for $2 \mathrm{~min}$ ) in a Mastercycler personal thermal cycler (Eppendorf). The polymerization was concluded by an extension period of $10 \mathrm{~min}$ at $68^{\circ} \mathrm{C}$. The RT-PCR product was visualized by electrophoresis in $1 \%$ agarose gels.

\section{RESULTS}

\section{Virus isolation}

Kidney and spleen homogenates from $50 \%$ of the Greenland halibut analyzed (15 of 30 fish) produced CPE on EPC cells. The sizes of fish with viruses ranged between 250 and $1500 \mathrm{~g}$. In 5 samples, the effect was evident in the first passage after $10 \mathrm{~d}$ post-inoculation, whereas the remaining positive samples developed CPE only after a second blind passage.

The CPE consisted of rounded, retractile cells dislodged from the monolayers, resulting finally in total destruction of the monolayer. None of the homogenates from the other fish species analyzed (Atlantic cod, American plaice and witch flounder) developed $\mathrm{CPE}$ on this cell line. Other isolates were recovered in CHSE-214 cells, and later identified as aquatic birnaviruses (Bandín et al. 1997). Their characterizations will be published elsewhere.

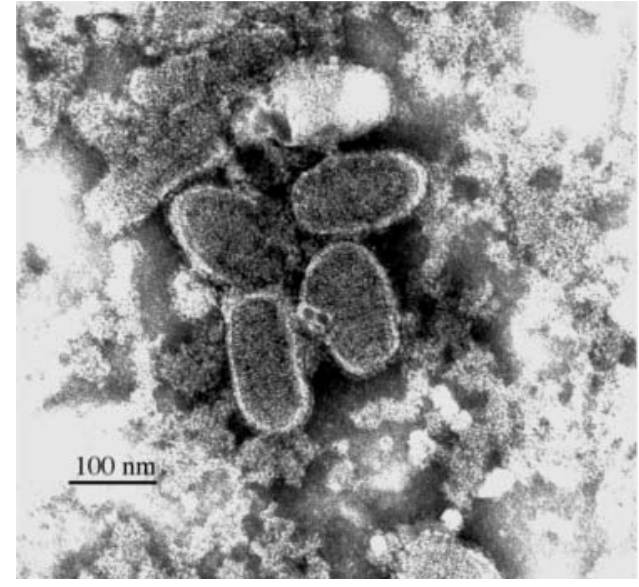

Fig. 2. Electron micrograph showing enveloped bullet-shaped viral particles in halibut

\section{Viral identification}

The viral samples were sensitive to chloroform, since this treatment completely inactivated the viruses (data not shown). Electron micrographs of the negatively stained virus (Fig. 2) showed enveloped bullet-shaped viral particles of around $80 \times 165 \mathrm{~nm}$. All 15 isolates were neutralized by the antiserum against the European VHS F1 strain in the direct neutralization tests (no cross-reaction was observed with either of the negative controls included, i.e. IHNV and IPNV). Occasionally neutralization of IHNV with this antiserum was observed at a dilution of $\leq 1 / 30$. No neutralization was observed at a dilution of $1 / 10$. However, it must be pointed out that the neutralization titers were relatively low for most of the isolates. As shown in Table 1, the titer of the antiserum was 1/1188 (close to the homologous titer of 1/1594) only with Isolate GH32, while the remaining strains showed low (1/316) or

Table 1. Neutralization titers of Greenland halibut viral hemorrhagic septicemia virus (VHSV) isolates, using an antiserum against the European F1 strain. Data are expressed as the reciprocal of the $50 \%$ endpoint

\begin{tabular}{|ll|}
\hline Heterologous titer & Isolates \\
\hline $1 / 316$ & GH34, GH35, GH36,GH42, \\
$1 / 630$ & GH45, GH47, GH48, \\
$1 / 891$ & GH43 \\
& GH30, GH33, GH37, GH40, \\
$1 / 1188$ & GH44, GH46 \\
Homologous titer: 1/1594 & GH32 \\
\hline
\end{tabular}




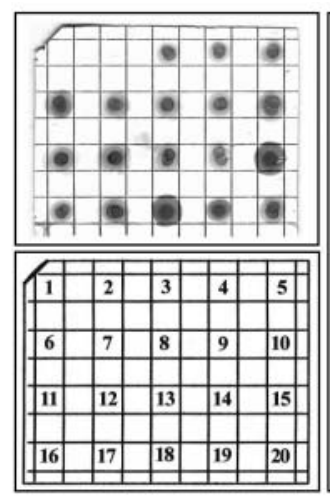

\section{Negative Control \\ 1.- IHNV \\ 2.- EMEM}

Positive Control

3-5.- VHSV F1

Greenland halibut isolates

6.- GH30 11.- GH36 16.- GH44

7.- $\mathrm{GH} 32$ 12.- GH37 17.- GH45

8.- GH33 13.- GH40 18.- GH46

9.- GH34 14.- GH42 19.- GH47

10.- GH35 15.- GH43 20.- GH48

Fig. 3. VHSV virus identified from the Greenland halibut by the immunodot technique using a polyclonal antiserum against the F1 strain. EMEM: Eagle's minimum essential

medium; IHNV: infectious hematopoietic necrosis virus

moderate $(1 / 630$ or $1 / 891)$ titers. Moreover, none of the isolates was neutralized by the antisera anti-IHNV.

The immunodot assay using the same antiserum showed positive reaction with all the isolates (Fig. 3), as well as with Strain VHSV F1, used as a positive control. No reaction was observed with the negative controls (IHNV and EMEM). On the other hand, none of the samples reacted with the antiVHSV MAb IP5 B11 in the immunofluorescence tests nor with the kit from Bio-X.

The 15 viral isolates were identified as VHSV by RT-PCR, since an amplified product of $434 \mathrm{bp}$ was obtained when the technique was applied to total RNA extracted from infected cells (Fig. 4). No fragment was amplified when primers for IHNV were used.

\section{Host range in vitro}

The results of the cell line-susceptibility assay are shown in Table 2. Cultures other than EPC were susceptible to the viral isolates at both temperatures assayed $\left(10\right.$ and $\left.15^{\circ} \mathrm{C}\right)$. The optimum temperature for viral replication was $15^{\circ} \mathrm{C}$; at this temperature, the time for development of CPE and total destruction of the monolayers was generally shorter than at $10^{\circ} \mathrm{C}$. Moreover, $40 \%$ of the isolates were not infective in CHSE-214 at $10^{\circ} \mathrm{C}$. TV-1 was the most susceptible cell line since most of the isolates developed CPE in 1 to $3 \mathrm{~d}$ postinoculation (p.i.) $(1.4 \pm 0.63)$, resulting in destruction of the monolayer in 2 to $4 \mathrm{~d}$. The detection of the virus was a little slower in $\mathrm{EPC}$ at $10^{\circ} \mathrm{C}$, first signs of CPE being observed in an average time of $2.2 \pm 0.75 \mathrm{~d}$ p.i., and complete destruction occurring between the second and fourth days. RTG-2 also showed high susceptibility, while the remaining 2 cell lines were less susceptible. With BB cells it was not possible to perform the assay at $10^{\circ} \mathrm{C}$ because the cells detached at this temperature.

The results of cell susceptibility in terms of viral titers were fairly similar at both temperatures. The highest virus yields were in EPCs, with viral titers averaging $8.1 \pm 0.85$ and $7.8 \pm 1.0 \operatorname{logs}$ of $\mathrm{TCID}_{50}$ at 10 and $15^{\circ} \mathrm{C}$, respectively. In the other cells lines, titers were generally 1 to 2 logs lower.

\section{DISCUSSION}

The Greenland halibut analyzed in this study were caught at the Flemish Cap, a fishing ground in international waters in the North Atlantic Ocean. Most of the fish species in this area live in an isolated environment because of the depth of the Flemish Pass (1100 m), which prevents or reduces migration. However, the

Table. 2. Cell line susceptibility of Greenland halibut isolates at different temperatures. VHSV F1: time, in days post-infection for development of cytopathic effect $(\mathrm{CPE})$ by the reference strain; Time: average $( \pm \mathrm{SD})$ time for detection of $\mathrm{CPE}$ or total destruction of the monolayer by the Greenland halibut isolates; $\%$ Infect: percentage of isolates developing CPE or displaying complete destruction of the cell monolayer; Titer: average $( \pm \mathrm{SD})$ titer expressed as log of $\mathrm{TCID}_{50}$ $\mathrm{ml}^{-1}$; na: not applicable, since cell monolayer is affected by the temperature; -: no CPE and/or complete destruction observed. (Cell lines described in first subsection of 'Materials and methods'

\begin{tabular}{|c|c|c|c|c|c|c|c|}
\hline \multirow{2}{*}{$\begin{array}{l}\text { Cell line } \\
\text { Temp }\left({ }^{\circ} \mathrm{C}\right)\end{array}$} & \multicolumn{3}{|c|}{$\mathrm{CPE}$} & \multicolumn{3}{|c|}{ Complete destruction } & \multirow[t]{2}{*}{ Titer } \\
\hline & $\begin{array}{c}\text { VHSV } \\
\text { F1 }\end{array}$ & Time & $\%$ Infect & $\begin{array}{c}\text { VHSV } \\
\text { F1 }\end{array}$ & Time & $\%$ Infect & \\
\hline \multicolumn{8}{|l|}{ EPC } \\
\hline 10 & 5 & $5.3 \pm 0.6$ & 100 & 7 & $6.6 \pm 0.6$ & 100 & $8.1 \pm 0.8$ \\
\hline 15 & 2 & $2.2 \pm 0.7$ & 100 & 3 & $3.2 \pm 0.7$ & 100 & $7.8 \pm 1.0$ \\
\hline \multicolumn{8}{|l|}{ CHSE-214 } \\
\hline 10 & 3 & $2.3 \pm 0.7$ & 60 & 4 & $3.5 \pm 0.7$ & 60 & $6.2 \pm 0.9$ \\
\hline 15 & 3 & $4.1 \pm 2.5$ & 100 & 7 & $3.9 \pm 1.7$ & 60 & $6-7 \pm 0.6$ \\
\hline \multicolumn{8}{|l|}{ RTG-2 } \\
\hline 10 & 7 & $6.3 \pm 1.2$ & 87 & 8 & $7.2 \pm 1.3$ & 87 & $7.3 \pm 0.7$ \\
\hline 15 & 2 & $2.1 \pm 0.3$ & 100 & 4 & $3.4 \pm 0.6$ & 100 & $7.3 \pm 0.6$ \\
\hline \multicolumn{8}{|l|}{ TV-1 } \\
\hline 10 & 6 & $5.4 \pm 0.9$ & 100 & 7 & $6.6 \pm 1.0$ & 100 & $7.6 \pm 0.5$ \\
\hline 15 & 2 & $1.4 \pm 0.6$ & 100 & 4 & $2.8 \pm 1.0$ & 100 & $7.5 \pm 0.5$ \\
\hline \multicolumn{8}{|l|}{ BB } \\
\hline 10 & na & na & na & na & na & na & na \\
\hline 15 & - & $4.0 \pm 1.7$ & 74 & - & $7.6 \pm 0.6$ & 33 & $6.8 \pm 0.4$ \\
\hline
\end{tabular}



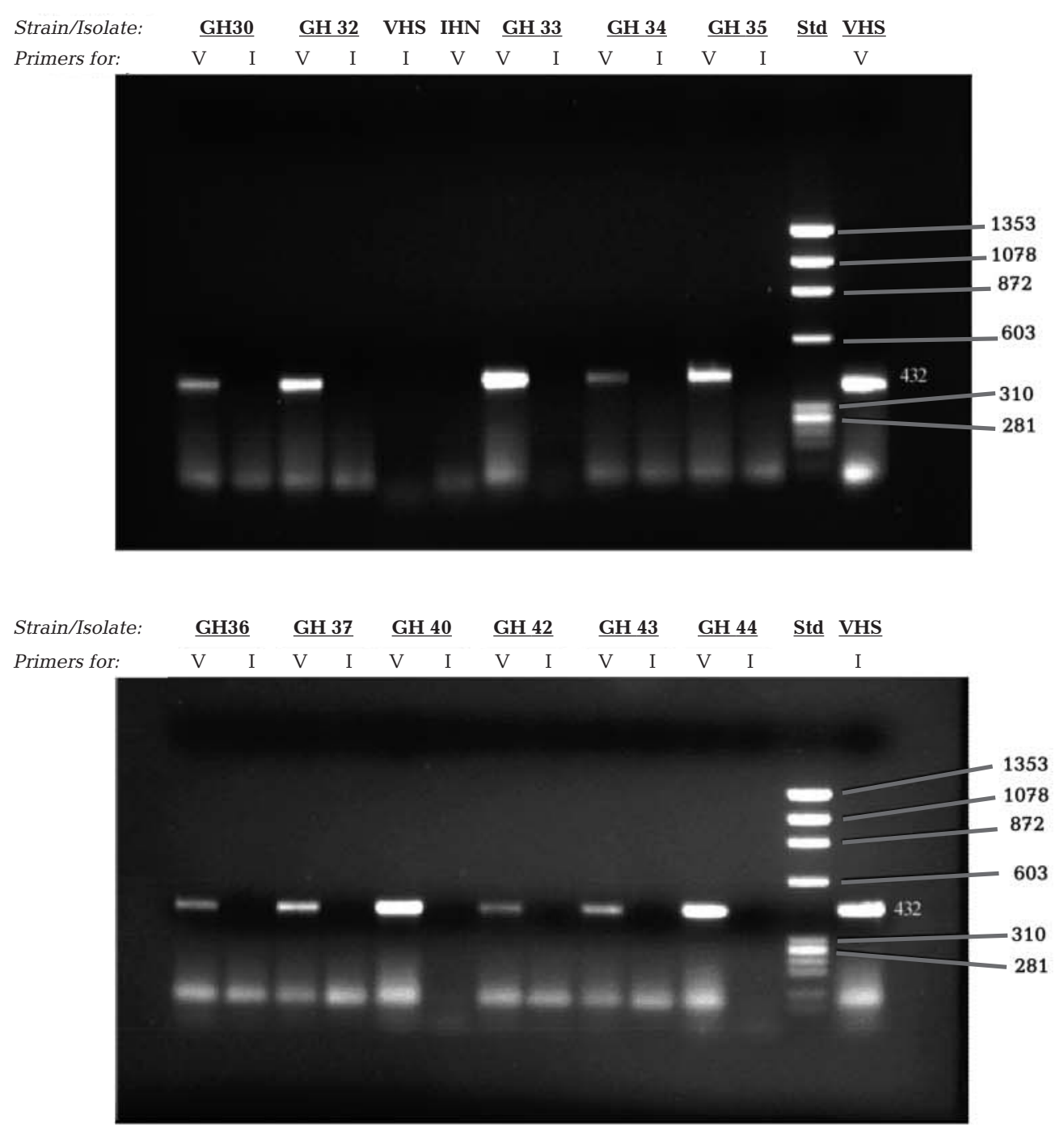

Strain/Isolate:

Primers for:

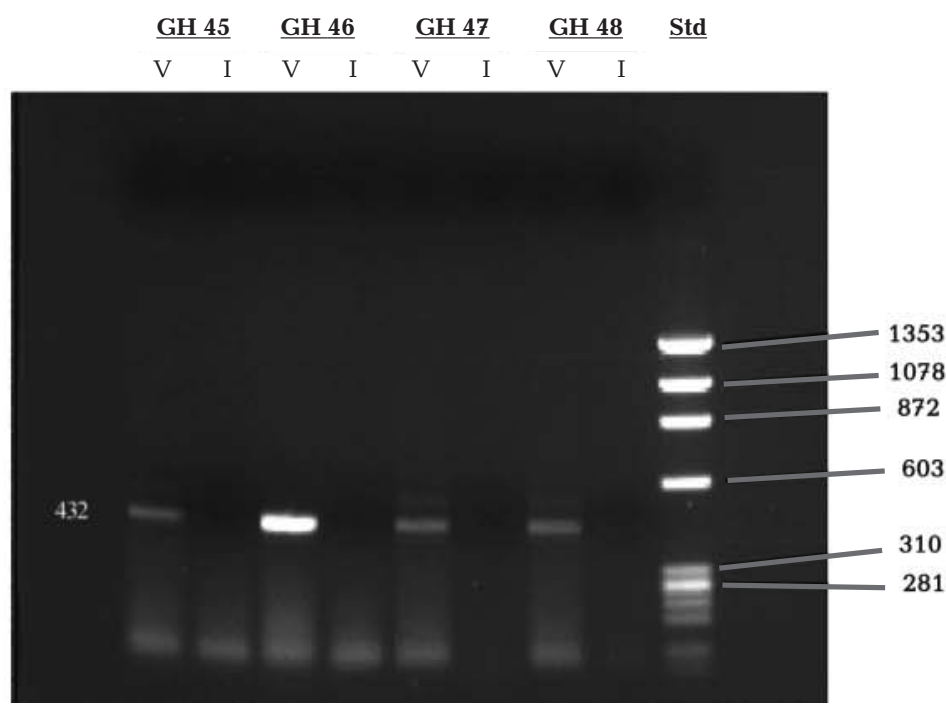

Fig. 4. Agarose gels showing the RT-PCR products obtained from Greenland halibut isolates using specific primers for VHSV (Lanes V) and IHNV (Lanes I). Standard (Std.) size markers: $\phi X 174 /$ Hae III (sizes shown as number of bp) 
Flemish Pass is not a barrier for Greenland halibut, which usually inhabit deep areas and migrate through Greenland, the Davis Strait, Labrador and Terranova, and constitute a single population (Anonymous 1994).

Physicochemical characterization, electron microscopy, and a serological assay indicated that the 15 isolates from the Greenland halibut belonged to the family Rhabdoviridae and were identified as VHSV by means of RT-PCR.

Although the virus was isolated in EPC cells, susceptibility assays revealed that TV-1 cells were more susceptible, at least in terms of time for detection of the virus. This supports the requirement of employing more than one cell line for viral isolation. In this sense, EPC cells have been used for the isolation of VHSV with contradictory results: whereas Jensen et al. (1979) and Schlotfeldt et al. (1991) reported that isolates from Atlantic cod and turbot produced a minimal CPE in EPC cells even with serial passages, other authors indicated that VHSV of marine origin grew to highest titers in EPC (Batts et al. 1991). In fact, higher titers were also obtained in EPC cells in the present study.

In the serological analysis, all the isolates reacted in the immunodot assay with a polyclonal antiserum against the European VHSV Type Strain F1. However, it is interesting that this antiserum showed low or moderate neutralization titers with most of the isolates, indicating that they cannot be confirmed as Type F1. In addition, none of the isolates reacted in the IFAT assay with the MAb IP5B11, specific against a nucleocapsidrelated protein (Lorenzen et al. 1988). This result highlights the risk of using specific monoclonal antibodies for detection of this virus, at least in wild populations, where the existence of new types is to be expected. Moreover, the fact that the commercial IFAT kit did not identify these isolates as VHSV is in agreement with the results of Ariel \& Olesen (2001), who suggested that commercial diagnosis kits need to be validated by testing a wide range of isolates.

A complete description of the serological relationship between viruses requires cross-neutralization tests using both homologous and heterologous antisera, followed by calculation of cross-neutralization values (Archeti \& Horsfall 1950). Although cross-neutralization was not carried out with the Greenland halibut isolates, we believe that the neutralization titers might be used as an approach to determine the relationship among our isolates and the F1 strain. Previous studies using antisera against that strain (4 neutralizing MAbs against the viral glycoprotein and 1 polyclonal antisera) have demonstrated antigenic diversity among European isolates of VHSV, establishing 3 reaction patterns but only 1 major serotype (Olesen et al. 1993). Although distinguishable from the European strains by genotyping with molecular techniques (Batts et al. 1993, Einer-Jensen et al. 1995, Benmansour et al. 1997, Snow et al. 1999), all North American isolates of VHSV isolated in the Pacific coast, from either salmonids or marine fishes, have been identified as Type F1 strains using the plaque neutralization test and IFAT with a polyclonal antisera (Meyers et al. 1992, 1994, Meyers \& Winton 1995). Therefore, having regard to the location of the area where the fish were caught, and the serological techniques used, most of the Greenland halibut VHSV isolates would be expected to be of the F1 type. However, the relatively low neutralization titers recorded in the present study do not support this hypothesis.

Olesen et al. (1993) reported that isolates showing Pattern III were not neutralized by any of the 4 MAbs, and only moderately neutralized, or not neutralized at all, by the rabbit antiserum; this is similar to the results of the present study. Based on our findings, it is obvious that there are antigenic differences between the Greenland halibut isolates and the European reference strain, but it seems also clear that at least some neutralizing epitopes must be shared. Furthermore, the results of the IFAT assay indicate that the nucleocapsid-related protein against which this particular MAb was produced possesses at least 1 epitope that is not shared equally by all VHSV isolates, and shows that antigenic variations may not only be present in the glycoprotein, but also in internal proteins. Further studies involving a higher number of MAbs, or applying molecular techniques, will be necessary to conclusively type the Greenland halibut isolates.

The isolation of the virus from $50 \%$ of the Greenland halibut analyzed suggests a considerably high prevalence of VHSV in the population. However, only 5 of the 15 positive samples produced CPE $10 \mathrm{~d}$ p.i., whereas the remaining 10 isolates needed a second blind passage to develop CPE. This seems to indicate a low level of virus in each individual fish, and was confirmed by the low or even undetectable levels of virus in the tissues (data not shown). This apparently low level of infection, together with the asymptomatic state of the fish, led us to believe that Greenland halibut could be a reservoir for VHSV rather than a species susceptible to the disease. Of course we cannot rule out the possibility that stressful conditions or the concomitant presence of other potentially infectious agents could lead to the development of a disease.

The detection of VHSV in the North Atlantic Ocean indicates that the virus is more widely distributed than was thought, and that it is not restricted to specific areas of Europe (mainly British coastal waters, and the Baltic and North Seas) and the North Pacific coast of North America, where marine isolations of VHSV had been reported to date. This extension of the geographical range of VHSV could be due to an increase of the 
monitoring of marine fishes in recent years. Another possible explanation could be the spreading of the virus during migration of the halibut since, according to 'Flemish Cap '94' biologists, Greenland halibut forms a unique population migrating from Norway, Svalbard islands and Iceland to the Great Banks. However, to our knowledge no isolations of VHSV have been made from salmonids or marine fishes on the Atlantic coast of North America. These arguments would also support the hypothesis of a marine origin for VHSV, which has been suggested repeatedly in the literature in the last few years (Batts et al. 1993, Meyers et al. 1994, Meyers \& Winton 1995, Dixon et al. 1997, Stone et al. 1997, Dixon 1999). Nevertheless, more data (e.g. molecular comparison with continental pathogenic strains) is necessary to confirm this hypothesis.

It has been reported that VHSV isolates from North America and Europe constituted 2 genetically distinct groups of the virus (Batts et al. 1993, Basurco et al. 1995, Einer-Jensen et al. 1995, Benmansour et al. 1997). Further analysis is necessary to determine the relatedness between the Greenland halibut isolates and the European and/or North American strains.

Acknowledgements. We thank Dr. N. J. Olesen for kindly providing the anti-VHS serum and the monoclonal antibody. We also thank the chief scientist of 'Flemish Cap '94', Dr. A. Vázquez, for allowing us to participate in this campaign, Carlos R. Osorio and F. Villoch for the collection of samples, and the crew of the 'Cornide de Saavedra'. This work was supported by grants 1FD97-0953-C02-02 and MAR99-0637-C0201 from the Comisión Interministerial de Ciencia y Tecnología (FEDER-CICYT and DGSIC, respectively). This represents Scientific Contribution No. 006/2001 of the Instituto de Acuicultura.

\section{LITERATURE CITED}

Anonymous (1994) Scientific report of the research campaign Flemish Cap'94. Instituto de Investigacións Mariñas, Vigo

Archeti I, Horsfall FL (1950) Persistent antigenic variation of influenza A viruses after incomplete neutralization in vivo with heterologous immune serum. J Exp Med 92:441-462

Ariel E, Olesen NJ (2001) Assessment of a commercial kit collection for diagnosis of the fish viruses: IHNV, IPNV, SVCV and VHSV. Bull Eur Assoc Fish Pathol 21:6-11

Bandín I, Silva A, Olveira JG, Cutrín JM, Dopazo CP, Barja JL (1997) Virus in marine wild fish. Proceedings of the Eighth International Conference of the European Association of Fish Pathologists, Edinburgh, p 001

Basurco B, Vende P, Monnier AF, Winton JR, de Kinkelin P, Benmansour A (1995) Genetic diversity and phylogenetic classification of viral hemorrhagic septicemia virus (VHSV). Vet Res (Paris) 26:460-463

Batts WN, Traxler GS, Winton JR (1991) Factors affecting the efficiency of plating for selected fish rhabdoviruses. Proceedings of the Second International Symposium on Viruses of Lower Vertebrates, Corvallis, OR, p 17-24

Batts WN, Arakawa CK, Bernard J, Winton JR (1993) Isolates of viral hemorrhagic septicemia virus from North America and Europe can be detected and distinguished by DNA probes. Dis Aquat Org 17:67-71

Benmansour A, Basurco B, Monnier AF, Vende P, Winton JR, de Kinkelin P (1997) Sequence variation of the glycoprotein gene identifies three distinct lineages within field isolates of viral haemorrhagic septicaemia virus, a fish rhabdovirus. J Gen Virol 78:2837-2846

Brunson R, True K, Yancey J (1989) VHS virus isolated at Makah National Fish Hatchery. Newsl Am Fish Soc Fish Health Sect 17:3-4

Cox B, Hedrick RP (2001) VHS virus in Pacific sardines and mackerel. Newsl Am Fish Soc Fish Health Sect 29:3

Dixon PF (1999) VHSV came from the marine environment: clues from the literature, or just red herrings? Bull Eur Assoc Fish Pathol 19(2):60-65

Dixon PF, Feist S, Kehoe E, Parry L, Stone DM, Way K (1997) Isolation of viral haemorrhagic septicaemia virus from Atlantic herring Clupea harengus from the English Channel. Dis Aquat Org 30:81-89

Dopazo CP, Toranzo AE, Samal SK, Roberson BS, Baya A, Hetrick FM (1992) Antigenic relationships among rotaviruses isolated from fish. J Fish Dis 15:27-36

Eaton WD, Hulett J, Brunson R, True K (1991) The first isolation in North America of infectious hematopoietic necrosis virus (IHNV) and viral hemorrhagic septicemia virus (VHSV) in coho salmon from the same watershed. J Aquat Anim Health 3:114-117

Einer-Jensen K, Olesen NJ, Lorensen N, Jørgensen PEV (1995) Use of the polymerase chain reaction (PCR) to differentiate serologically similar viral haemorrhagic septicaemia (VHS) virus isolates from Europe and America. Vet Res Paris 26:464-469

Hamparian VV, Hilleman MR, Kettler A (1963) Contributions to characterization and classification of animal viruses. Proc Soc Exp Biol Med 206:736-740

Hershberger PK, Kocan RM, Elder NE, Meyers TR, Winton JR (1999) Epizootiology of viral hemorrhagic septicemia virus in Pacific herring from the spawn-on-kelp fishery in Prince William Sound, Alaska, USA. Dis Aquat Org 37:23-31

Hopper K (1989) The isolation of VHSV from chinook salmon at Glenwood Springs, Orcas Island, Washington. Newsl AM Fish Soc Fish Health Sect 17:1

Jensen NJ, Bloch B, Larsen JL (1979) The ulcus-syndrome in cod (Gadus morhua). III. A preliminary virological report. Nord Vetmed 31:436-442

Jørgensen PEV (1972) Egtved virus: antigenic variation in 76 virus isolates examined in neutralization tests and by means of the fluorescent antibody technique. Symp Zool Soc Lond 30: 333-340

Jørgensen PEV, Olesen NJ (1987) Cod ulcus syndrome rhabdovirus is indistinguishable from the Egtved (VHS) virus. Bull Eur Assoc Fish Pathol 7:73-74

Kaufman J, Holt RA (2001) Isolation of North American viral hemorrhagic septicemia virus (VHSV) from Columbia river smelt (Thaleichthys pacificus). Newsl Am Fish Soc Fish Health Sect 29:1-3

Kent ML, Traxler GS, Kieser D, Richard J and 5 others (1997) Survey of salmonid pathogens in ocean-caught fishes in British Columbia, Canada. J Aquat Anim Health 10:211-219.

King JA, Snow M, Smail DA, Raynard RS (2001) Distribution of viral haemorrhagic septicaemia virus in wild fish species of the North Sea, North East Atlantic Ocean and Irish Sea. Dis Aquat Org 47:81-86

Lorenzen N, Olesen NJ, Jørgensen PEV (1988) Production and characterization of monoclonal antibodies to four 
Egtved virus structural proteins. Dis Aquat Org 4:35-42

Marty GD, Freiburg EF, Meyers TR, Wilcock J, Farver TB, Hinton DE (1998) Viral hemorrhagic septicemia virus, Ichthyophonus hoferi, and other causes of morbidity in Pacific herring Clupea pallasi spawning in Prince William Sound, Alaska, USA. Dis Aquat Org 32:15-40

Meier W, Schmitt M, Wahli T (1994) Viral haemorrhagic septicaemia (VHS) of non salmonids. Annu Rev Fish Dis 4:359-373

Meyers TR (1979) A Reo-like virus isolated from juvenile American oysters (Crassostrea virginica). J Gen Virol 43:203-212

Meyers TR, Winton JR (1995) Viral hemorrhagic septicemia virus in North America. Annu Rev Fish Dis 5:3-24

Meyers TR, Sullivan J, Emmenegger E, Follett J, Short S, Batts WN, Winton JR (1992) Identification of viral hemorrhagic septicemia virus isolated from Pacific cod Gadus macrocephalus in Prince William Sound, Alaska, USA. Dis Aquat Org 12:167-175

Meyers TR, Short S, Lipson K, Batts WN, Winton JR, Wilcock J, Brown E (1994) Association of viral hemorrhagic septicemia virus with epizootic hemorrhages of the skin in Pacific herring Clupea harengus pallasi from Prince William Sound and Kodiak Island, Alaska, USA. Dis Aquat Org 19:27-37

Meyers TR, Short S, Lipson K (1999) Isolation of the North American strain of viral hemorrhagic septicemia virus (VHSV) associated with epizootic mortality in two new host species of Alaskan marine fish. Dis Aquat Org 38:81-88

Mortensen HF (1999) Isolation of viral haemorrhagic septicaemia virus (VHSV) from wild marine fish species in the Baltic Sea, Kattegat, Skagerrak and the North Sea. Virus Res 63:95-106

Munro ALS (1996) First recorded outbreak of viral haemorrhagic septicaemia (VHS) in GB and subsequent actions to contain, eradicate and investigate the origins of the infection. Scottish Office Agriculture, Environment and Fisheries Department, Aberdeen (Scottish Aquaculture Research Report No 3).

Editorial responsibility: Jo-Ann Leong, Corvallis, Oregon, USA
Okamoto N, Sano T, Hedrick RP, Fryer JL (1983) Antigenic relationships of selected strains of infectious pancreatic necrosis virus and European eel virus. J Fish Dis 6:19-25

Olesen NJ, Lorenzen N, Jørgensen PEV (1993) Serological differences among isolates of viral haemorrhagic septicaemia virus detected by neutralizing monoclonal and polyclonal antibodies. Dis Aquat Org 16:163-170

Reed LJ, Muench H (1938) A simple method of estimating fifty percent endpoints. Am J Hyg 27:439-502

Ross K, McCarthy U, Huntly PJ, Wood BP, Stuart D, Rough EI, Smail DA, Bruno DW (1994) An outbreak of viral haemorrhagic septicaemia (VHS) in turbot (Scophthalmus maximus) in Scotland. Bull Eur Assoc Fish Pathol $14: 213-214$

Schlotfeldt HM, Ahne W, Jørgensen PEV, Glende W (1991) Occurrence of viral haemorrhagic septicaemia in turbot (Scophthalmus maximus) - a natural outbreak. Bull Eur Assoc Fish Pathol 11:105-107

Smail DA (1995) Isolation and identification of viral haemorrhagic septicaemia (VHS) virus from North Sea cod (Gadus morhua L.). ICES Comm Meet 1995/F:15:1-6

Smail DA (2000) Isolation and identification of viral haemorrhagic septicaemia (VHS) viruses from cod Gadus morhua with the ulcus syndrome and from haddock Melanogrammus aeglefinus having skin haemorrhages in the North Sea. Dis Aquat Org 41:231-235

Snow M, Cunninham CO, Melvin WT, Kurath G (1999) Analysis of the nucleoprotein gene identifies distinct lineages of viral haemorrhagic septicaemia virus within the European marine environment. Virus Res 63:35-44

Stone DM, Way K, Dixon PF (1997) Nuceotide sequence of the glycoprotein gene of viral haemorrhagic septicaemia (VHS) viruses from different geographical areas: a link between VHS in farmed fish species and viruses isolated from North Sea cod (Gadus morhua L.). J Gen Virol 78:1319-1326

Traxler GS, Kieser D (1994) Isolation of the North American strain of viral hemorrhagic septicemia virus (VHSV) from herring (Clupea harengus pallasi) in British Columbia. Newsl Am Fish Soc Fish Health Sect 22:8

Submitted: October 19, 2001; Accepted: February 17, 2002 Proofs received from author(s): July 9, 2002 